other words, using a non-parametric test the study does lend support for the beneficial effect of sodium restriction. In view, however, of the large fall in blood pressure that occurred irrespective of sodium intake during the first month's treatment period, we believe that the study is inconclusive and should not be used as evidence for the value of sodium restriction in mild hypertension.

As we stated in our last letter more evidence for the value of sodium restriction is required. In the meantime, and until this evidence is obtained, our own advice to patients with hypertension is to continue moderate restriction of sodium intake, a manoeuvre which is likely to be as effective as a diuretic but without the metabolic problems associated with diuretic treatment.

Graham MACGREgor NiRMala D Markandu Blood Pressure Unit, Charing Cross Hospital STEPHEN J SMITH

***This correspondence is now closed.-ED, $B M \mathcal{H}$.

Venous sampling in locating a phaeochromocytoma

SIR,-Dr D J Allison and others (2 April, $p$ 1122) have proposed an interesting and eminently practical sequence of investigation for patients with suspected phaeochromocytoma. I disagree, however, with the authors' suggested initial test-that is, the measurement of urinary vanillylmandelic acid.

The best strategy for identifying from among the many people with arterial hypertension the few who will turn out to have phaeochromocytomas is subject to controversy. A widely read textbook proclaims: "The basic screening investigation for phaeochromocytoma is the urinary vanillylmandelic acid." Another equally celebrated textbook states: "Metanephrines determinations are most satisfactory for initial testing."2 Yet another well known textbook assigns equal accuracy to both tests. ${ }^{3}$

An exhaustive search of the published work identified nine papers in English which reported at least 15 patients with proved phaeochromocytoma and detailed the characteristics of their control groups. ${ }^{4-12}$ Reports that seemed to include patients from previously published studies were excluded. The following data were collected from each publication: (a) The number of patients with phaeochromocytoma tested for urinary vanillylmandelic acid and urinary metanephrines or urinary catecholamines, or both; (b) the number of patients correctly identified by the tests used; (c) the characteristics of the control groups; $(d)$ the number of controls correctly identified by the tests used; $(e)$ the criteria used to define the normal range for the quantitative results of the tests used. For each test we calculated the sensitivity by dividing the total number of patients correctly identified by the total number of patients tested, and the specificity as the total number of controls having results within the defined normal range divided by the total number of subjects in the control groups.

The table shows the sensitivity and specificity of the three tests commonly used in screening for phaeochromocytoma. Measurement of urinary metanephrines seems to be the best test, followed by measurement of urinary vanillylmandelic acid and urinary catecholamines. False negative results were seen only when radiological procedures using contrast material containing methylglucamine preceded the urine collection by several days. ${ }^{14}$

Recent advances in the biochemical diag nosis of phaeochromocytoma-that is the analysis of fractional urinary free catecholamines using high pressure chromatography and amperometric detection have shown a sensitivity of $100 \%$ compared with $95 \%$ for urinary metanephrine and $89 \%$ for urinary vanillylmandelic acid. ${ }^{1314}$ The technique is costly, however, and, for the time being, should be used only for reliable confirmation of an abnormal screening test.

Department of Medicine,

Peter Manu

State University of New York

Upstate Medical Center

Syracuse,
New York,
USA

${ }^{1}$ Dollery CT. Arterial hypertension. In: Wyngaarden JB, Smith LH, eds. Cecil textbook of medicine. Philadelphia: WB Saunders Company, 1982:227. Holland OB. Pheochromocytoma. In: Isselbacher KJ, Adams RD, Braunwald E, Petersdorf RG, Wilson JD, eds. Harrison's principles of internal medicine. .73. Russel RP, Whelton PK. Systemic hypertension. In:
Harvey AM, Johns RJ, McKusick VA, Owens AH $\mathrm{Jr}$, Ross RS, eds. The principles and practice of medicine. New York: Appleton-Century-Crofts,

- Sjoerdsma A, Enselman K, Waldmann TA, Cooperman LH, Hammond WG. Pheochromocytoma: Current concepts of diagnosis

Engelman K, Portnoy B, Sjoerdsma A. Plasma catecholamine concentrations in patients with
hypertension. Circ Res 1970;26, 27; suppl $1: 1-141-5$. Gitlow SE, Mendlowitz M, Bertani LM. The biochemical techniques for detecting and establishing he presence of a pheochromocytoma. A review ten years' experience. Am f Cardiol 1970;26:270-9. Remine WH, Chong GC, van Heerden JA, Sheps SG, Harrison EG. Current management of pheochromocytoma. Ann Surg 1974;179:740-8.

Preo GA Jr, Stewart BA, Tarazi RC, Gifford RW. Preoperative blood transfusions in the safe surgical management of pheochromocyt

Bravo EL, Tarazi RC, Gifford RW, Stewart BH. Circulating and urinary catecholamines in phe chromocytoma. $N$ Engl F Med 1979;301:682-6

- Stewart BH, Bravo EL, Meaney TF. A new simplified approach to the diagnosis of pheochromocytoma. f Urol 1979;122:579-81

ones DH, Reid JL, Hamilton CA, Allison DJ,
Welbourn RB, Dollery CT. The biochemical diagnosis, localization and follow the biochemical cytoma: The role of plasma and urinary catecholacytoma: The role of plasma and urinary catech
mine measurements. $Q$ I Med 1980;49:341-61.

Plouin PF, Duclos JM, Menard J, Comoy E, Bohoun C, Alexandre JM. Biochemical tests for diagnosis of pheochromocytoma: Urinary versus plasma determinations. Br Med F 1981;282:853-4.

VanHeerden JA, Sheps SG, Hamberger B, Sheedy PF, Poston JG, Remine WH. Pheochromocytoma: Current statu

- Moyer TP, Jiang N-S, Tyce GM, Sheps SG. Analysis for urinary catecholamines by liomid chromatography with amperometric detection: methodology
and clinical interpretation of results. Clin Chem 1979; and clinical interpretation of results. Clin Chem 1979; 25:256-63.

Effectiveness of biochemical tests used in screening for phaeochromocytoma

\begin{tabular}{lcccc}
\hline Test & $\begin{array}{c}\text { No patients } \\
\text { studied }\end{array}$ & References & Specificity & Sensitivity \\
\hline Urinary vanillylmandelic acid & 294 & $4,6,7,8,9,11,12$ & 0.99 & 0.84 \\
Urinary metanephrines & 282 & $4,6,7,8,9,11,12$ & 0.99 & 0.96 \\
Urinary catecholamines & 179 & $4,7,8,11,12$ & 0.99 & 0.85 \\
\hline
\end{tabular}

\section{New drugs: antiarrhythmic drugs}

SIR,-Dr W S Hillis and Dr B Whiting (23 April, p 1332) recommend that for treatment of supraventricular tachycardia intravenous amiodarone be given at a dose of $3.5 \mathrm{mg} / \mathrm{kg}$ over five minutes. Later in their article they mention the possibility of resulting hypotension. We think, however, that the dangers of such a rapid infusion rate have not been adequately emphasised.

Recently, we treated 10 patients with tachyarrhythmias with intravenous amiodarone as the drug of first choice. In eight patients (four with supraventricular tachycardia, two with ventricular tachycardia, and two with tachycardia associated with a broad complex of the QRS segment) intravenous amiodarone was infused at the rate of $300 \mathrm{mg}$ over 10 minutes. Of these eight patients, four reverted to sinus rhythm but one of them developed severe hypotension. Two other patients became severely hypotensive after infusion without an appreciable rhythm change, and immediate direct current cardioversion was safely performed. We were unable to predict which patients were going to react badly to amiodarone on the basis of the type of arrhythmia, haemodynamic state, evidence of cardiomegaly, or serum potassium concentration. Despite the small size of our study we thought that the evidence was sufficiently strong for us to increase the infusion time to 30 minutes, and we had no problems in two subsequent patients.

There are examples in the published work bearing out our experience, ${ }^{1}$ including cases of fatal hypotension. Most of these seem to have followed fast rates of infusion of this drug. The manufacturer's current recommendations suggest a minimum infusion time of 20 minutes. We would caution against rapid infusion rates of intravenous amiodarone except in an extreme emergency.

M KOBLIC

M PETRI

Battle Hospital,

J A BELL

Reading

G3 1 AG

bi $M$, Studer $H$. Behandlung der arrhythmien 460-5.

\section{Bronchoconstriction in response to ipratropium bromide}

SIR,-Like Dr K R Patel and Dr W M Tullett (23 April, p 1318) and also Dr Connolly ${ }^{1}$ I too have encountered a mild atopic asthmatic patient who responded to nebulised ipratropium bromide ( $1 \mathrm{mg}$ ) with profound bronchoconstriction (forced expiratory volume in one second fell by half one hour after nebulisation). This did not occur with nebulised saline or cromoglycate and was rapidly reversed with metered dose salbutamol. Nebulisation of cromoglycate $(40 \mathrm{mg}) 30$ minutes before the ipratropium bromide converted the bronchoconstrictor response to a mild bronchodilator response (forced expiratory volume in one second increased by $10 \% 30$ minutes after nebulisation). The patient did not have appreciably hyperreactive airways (the provocative concentration of metacholine required to cause a $20 \%$ fall in the forced expiratory volume in one second was $0.19 \mathrm{mg} / \mathrm{ml}$ ), so it is unlikely that this idiosyncratic response is purely a reflection of non-specific airway hyperreactivity.

I have not experienced this response in patients with severe chronic airflow obstruc- 